\title{
Conducting Natural Resource Assets Departure Audit on Leading Cadres
}

\author{
Wenyao Zhang \\ Jinan University, Guangzhou, China \\ Email: 370601134@qq.com
}

How to cite this paper: Zhang, W.Y. (2018) Conducting Natural Resource Assets Departure Audit on Leading Cadres. Journal of Service Science and Management, 11, 36-43.

https://doi.org/10.4236/jssm.2018.111004

Received: December 25, 2017

Accepted: February 4, 2018

Published: February 7, 2018

Copyright $\odot 2018$ by author and Scientific Research Publishing Inc. This work is licensed under the Creative Commons Attribution International License (CC BY 4.0).

http://creativecommons.org/licenses/by/4.0/

\begin{abstract}
As an important institutional innovation of ecological civilization construction, natural resource assets departure audit has many issues to be explored. This paper systematically summarizes its implemental situation and the current status of the theoretical research. We hold the point that the performers of conducting natural resource assets departure audit can only be the government audit offices, the auditees of departure audit ought to be the government leading officials, as well as the heads of state-owned enterprises. The audit content is various natural resources, but each province should determine the resource items that should be focused on from the actual situation. Finally, we provide some suggestions to perfect natural resource assets departure audit.
\end{abstract}

\section{Keywords}

Natural Resource Assets Departure Audit on Leading Cadres, Auditors, Auditee, Contents

\section{Introduction}

Natural resources are the basis for human survival and development, and the wealth shared by the whole nation. As a socialist country, the leading cadres of all government levels represent the whole nation to exercise the ownership responsibility of the state-owned natural resources assets in China, including planning and classification of assets, assets registration, transfer and so on [1]. But, do the leading cadres exercising their ownership responsibility in the right way? If the use of natural resources can be reported and disclosed to the whole nation in a quantified manner, the owner will have a more clear understanding. It can not only supervise and urge the leading cadres to plan and use natural re- 
sources rationally, but also be a more responsible representation of the whole nation. Therefore, reporting and disclosure the use of natural resources has become a practical necessity.

Under the new normal economy, "The decision of the central committee of the communist party of China on comprehensively deepening reform" produced by the third plenary session of 18th communist party of China central committee put forward "compiling balance sheet of natural resources and conduct natural resource assets departure audit on leading cadres". In brief, the value of natural resources such as mountain, water, forest, farmland and lake is quantified, which can be evaluated, calculated and traded on this basis. After conducting natural resource assets departure audit, it will be clear in the future that when a leading cadre retired, whether the assets of natural resources have become larger and better, or they have become less and worse compare to the time he took up an official post. At the same time, we should focus on authenticity, which means whether it is prepared in accordance with the applicable reports in all major respects, and the audit opinion is issued in a fair way. This is not only a major institutional innovation to promote the construction of ecological civilization, but also a new work field for audit supervision. Additionally, auditing natural resource assets can change the performance appraisal criteria that" only GDP matters" and set ecological civilization as an innovation point to enhance political achievements. Officials need to provide identification for their ecological construction during their tenures when leaving office, which will surely guide them to take full account of ecological factors and promote the construction of ecological civilization when making major decisions.

This paper analyzes the status quo of the theory and practice of natural resource assets departure audit. At present, the theory of natural resource assets departure audit is not perfect, research on the basic subject of audit, the object of responsibility and the content of the audit, and the practice is just a pilot phase. This paper analyzes the theory and practice of natural resource assets departure audit, found there are so many problems such as the lack of balance sheet and data collection in the implementation process, and then puts forward some strategies to perfect the natural resource assets departure audit, such as cultivating compound audit talents and determining audit emphases according to local conditions.

\section{The Process and Status Quo of Natural Resource Assets Departure Audit}

The trial of natural resource assets departure audit scheme is clear that it will be implemented in phases and steps from 2015 to 2017 [2]. Firstly, in 2015 and 2016, the pilot audit task is organized by the national audit office, and meanwhile local audit institutions, such as the provincial audit authorities shall arrange local audit pilot projects according to the actual situation. In the pilot work, the audit department should actively explore the audit object, audit con- 
tent, audit assessment, the definition of audit responsibilities and the use of audit results. Summarize constantly. Standardize gradually. Make full preparations to establish a regular audit system. Secondly, in 2017, the audit administration unified the audit agencies to carry out natural resource assets departure audit throughout the country. At the same time, the audit department, together with the relevant departments, should formulate the interim regulations. Thirdly, a regular audit system will be established since 2018 .

The audit of natural resources assets is a highly technical work, which requires high quality auditors. At present, various provinces and cities are actively exploring the contents and methods of audit. From a practical point of view, more than 8 provinces and cities had launched the government assets report pilot work in 2015. Pioneers are Guangdong, Guizhou, Jiangxi, Qinghai, Inner Mongolia, Hubei, Shandong and Chongqing. Since 2016, most provinces in China had officially started the pilot project of natural resources departure audit on leading cadres.

At present, the following difficulties exist in the pilot work in various places: 1) Information on the object of authentication required for Audit-General deficiency of Natural Resources balance sheet. From the reality of the audit work, the balance sheet of natural resources lagging behind, or even missing. 2) How to determine the quantity and value of natural resources assets and distinguish the merits and demerits of quality can not be solved. At this stage, the practice is to take the use, management and supervision of natural resources assets as the audit objective, and at the same time, combine the functions of relevant departments and units to determine the audit contents. For example: the forestry department mainly checks whether to complete the afforestation index, whether the forest resources management is in place and so on. 3) The information of natural resources assets is complex and complicated, and it is difficult to collect 4) At present, the evaluation index system of natural resources assets is not perfect, and the division of the responsibility of leadership is difficult.

Each of pilot city is facing difficulties in the implementation process, in addition to the experience that the pilot cities sum up in practice, the academic community is also actively discussing and exploring, providing policy makers with operational policy recommendations.

\section{The Status Quo of Theoretical Research on the Natural Resource Assets Departure Audit on Leading Cadres}

\subsection{Theoretical Basis}

\subsubsection{Principal-Agent Theory}

Under the current property right system of natural resources in china, there is a long and complex relationship between the initial owner and the final user of natural resources, as it is shown in Picture 1. It raises the difficulty of the principal's effective supervision over the agent and increases agency costs, forming 


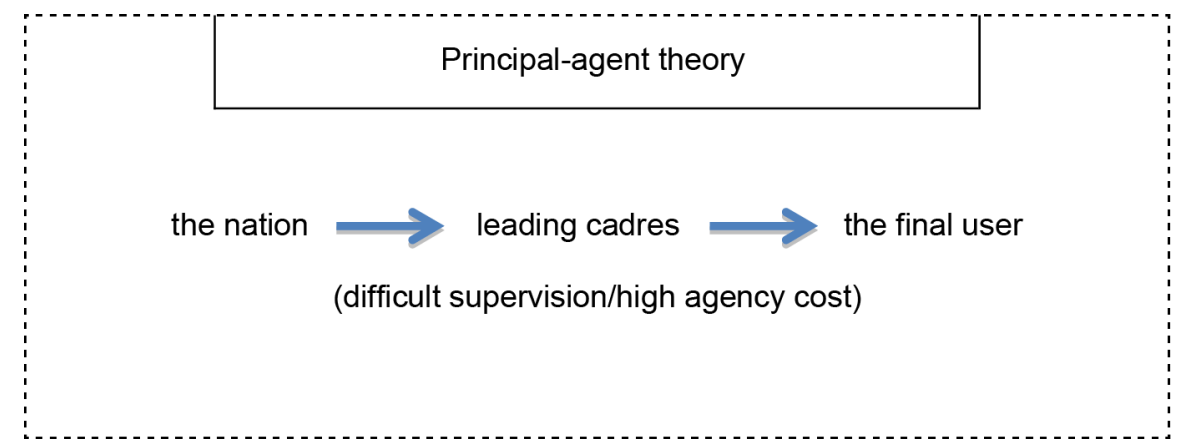

Picture 1. Description of principal-agent theory.

obstacles to reform. The establishment of natural resource assets departure audit on leading cadres can promote the effective performance of the entrusted economic responsibility of natural resources, and reduce the cost of entrusted agency, and thus enhance the welfare of the whole nation.

\subsubsection{The Fiduciary Responsibility View}

The government or leading cadres at all levels assume two duties under the current property right system of natural resources. On the one hand, they are responsible for the administrative management of natural resources assets and use the government's "visible hand" to correct the "market failure" in the natural resource allocation process caused by externalities and other causes [3] (Chen Bo, 2014), while on the other hand, they represent the whole nation to exercise the ownership responsibility of the state-owned natural resources assets, including planning and classification of assets, assets registration, transfer and so on. The clear fiduciary and fiduciary relationship and the separation of the naturel resource assets' ownership and management resulted in appearance of auditing. The leading cadres should fulfill obligations that they faithfully report the process and results of the fiduciary responsibility to all the citizens and to provide as much reliable information as possible. The process of reporting requires a third party supervisor who can deliver a true and fair view. Then natural resource assets departure audit emerge, as the times require.

\subsection{Academic Discussion}

It is a new step to include natural resources assets into the departure audit of leading cadres. There is only the economic duty audit before. However, the natural resources and the economy are different. We should establish a scientific and feasible calculation method to quantify and evaluate the natural resources assets. At present, the theoretical research of academic circles mainly focuses on such issues as "who examines", "whom to examine", "what to do" and "how to judge", which have not yet formed a mature system of departure audit method.

\subsubsection{Audit Subject}

There are different views on the audit subjects of the departure audit, such as "Monism", "pluralism" and "the monism is the main, the pluralism is the aux- 
iliary" view (Anhui audit department research group, 2014) [4]. We agree that the national audit agency is the best audit subject. Each audit subject has its own role in the field. From the perspective of each audit subject playing its role, internal audit is based on the internal responsibility relationship formed by the management decentralization, which plays a role in the internal affairs; the third party audit is based on the fiduciary responsibility relationship formed by the separation of ownership and management right, which mainly plays a role in the capital market. National audit is the main supervision department of the national governance system, which plays a major role in the field of public interest. Therefore, it is the duty of the state audit institution to supervise the use of natural resources assets' ownership and the exploitation and protection of natural resource assets.

\subsubsection{Responsible Object}

The object of departure audit includes both government leading cadres at all levels, as well as the heads of state-owned enterprises. Some scholars think that the heads of state-owned enterprises are the executor of the government policy, because it's the government who makes important decisions, so there is no need to include the heads of state-owned enterprises. However, based on out country's reality, state-owned enterprises occupy the main position in economic system. Moreover, resource-oriented state-owned enterprises occupy a large amount of natural resources, especially scarce resources and strategic resources. They shoulder an irreplaceable responsibility for the reasonable and efficient use of the natural resources to protect ecological environment. All subjects that are related to resource protection should be audited, and their responsible person naturally becomes the responsible object. Therefore, we think both government leaders and enterprise leaders shall consciously accept the departure audit and become harmonious culture atmosphere.

At the same time, natural resources assets departure audit should pay special attention to two key words: "natural resources assets" and "duty". That is to say, what kind of duties do leading cadres should perform for the natural resources assets in their jurisdiction area? Only by defining this standard can audit be more fair and reliable.

\subsubsection{Audit Content}

The content of natural resources assets departure audit and economic responsibility audit has both commonness and characteristics. It is characterized in that: according to Chen Bo's (2014) point of view, departure audit is a comprehensive audit including government financial audit, compliance audit and performance audit [3]. Government financial audit should focus on the collection and use of funds related to natural resources. Compliance audit refers to the authenticity and completeness of natural resources balance sheet and changes statement, etc. Performance audit mainly evaluates the economic benefits, social benefits and ecological benefits realized by the leading cadres when fulfilling the ownership of 
natural resources assets. Natural resources vary from place to place, thus the pilot units should identify the resources projects that should be focused on according to the actual situation.

The prerequisite for the smooth operation of the natural resources assets departure audit is to unify the guidelines for the compilation of the natural resource statements throughout the country. There are still many problems to be solved in this system innovation. Many scholars have expressed their own views on the guidelines for the compilation of reports. For examples, Huang Rongbing and Zhao Qian (2015) consider that the premise of preparing the natural resources balance sheet is to make sure that natural resources are valuable [5]. We should consider natural resources as assets or wealth. We should consider the natural resources' increase (growth, new discoveries and revaluation of value added) as capital formation. We should consider natural resources' reduction (exploitation, loss and revaluation) as the loss of capital. At the same time, we should establish the concept of natural resources liabilities, which means the cost to control the ecosystem or restore the state of natural resources. Finally, to achieve sustainable development. Cai Chun and Bi Mingyue (2014) proposed that natural resources balance sheet can be compiled in accordance with the principle of "assets = Liabilities + equity", and its basic structure is shown in Table 1 . The relatively simple natural resources change statement can reflect the significant changes in natural resource assets, and its basic structure is shown in Table 2. Rosa (2014) proposed that natural resources balance sheet can be compiled with embedded reports, independent reports and consolidated reports [6].

Table 1. Natural resources balance sheet.

\begin{tabular}{|c|c|c|c|c|}
\hline natural resources assets beginning balances & ending balance & natural resources liabilities and equity & beginning balances & ending balance \\
\hline assets & & liabilities & & \\
\hline land resources & & Payable land resources fee/tax & & \\
\hline water resources & & Payable water resources fee/tax & & \\
\hline air resources & & Payable air resources fee/tax & & \\
\hline Forest resources & & Payable forest resources fee/tax & & \\
\hline Grassland resources & & Payable grassland resources fee/tax & & \\
\hline ocean resources & & Payable ocean resources fee/tax & & \\
\hline mineral resources & & Payable mineral resources fee/tax & & \\
\hline Wild animal resources & & Payable wild animal resources fee/tax & & \\
\hline \multirow[t]{5}{*}{$\ldots \ldots$} & & total liability & & \\
\hline & & equity & & \\
\hline & & Initial natural resource capital & & \\
\hline & & Cumulative capital & & \\
\hline & & total equity & & \\
\hline Total assets & & total liability and equity & & \\
\hline
\end{tabular}

Source: Cai Chun, Bi Mingyue. Theoretical reflection on the natural resource assets departure audit audit research, 2014, (5). 
Table 2. Natural resources change statement.

\begin{tabular}{|c|c|c|c|c|}
\hline \multirow{2}{*}{ item } & \multicolumn{2}{|c|}{ beginning } & \multicolumn{2}{|c|}{ ending } \\
\hline & Debit & Credit & Debit & Credit \\
\hline \multicolumn{5}{|c|}{ natural resources assets } \\
\hline \multicolumn{5}{|c|}{ land resources } \\
\hline \multicolumn{5}{|c|}{ water resources } \\
\hline \multicolumn{5}{|c|}{ air resources } \\
\hline \multicolumn{5}{|c|}{ forest resources } \\
\hline \multicolumn{5}{|c|}{ grassland resources } \\
\hline \multicolumn{5}{|c|}{ ocean resources } \\
\hline \multicolumn{5}{|c|}{ mineral resources } \\
\hline \multicolumn{5}{|c|}{ Wild animal resources } \\
\hline \multicolumn{5}{|l|}{$\ldots \ldots$} \\
\hline \multicolumn{5}{|c|}{ others } \\
\hline Total inflow (o & urce ass & he curre & & \\
\hline
\end{tabular}

Source: Cai Chun, Bi Mingyue. Theoretical reflection on the natural resource assets departure audit audit research, 2014, (5).

In addition to the discussion of the basic problems above, the existing literature research also studies the problems existing in the natural resource assets departure audit and the countermeasures of it. In general, the results of theoretical research are abundant, including the research on audit definition, audit target, audit scope, audit object, audit content and so on. But the research of application is not mature enough, including the research on the problems existing in the audit practice, and the suggestion of how to improve the audit problem are not enough. On the whole, the research is in the primary stage, and the empirical research results are less. The academic research on the natural resource assets departure audit should be based on the perfect theory, discuss the practical application of audit, and increase the empirical research. In order to promote the practice of the natural resource assets departure audit, advance the process of practice and realize the effective protection of natural resources.

\section{Suggestions for Perfecting Natural Resource Assets Departure Audit}

\subsection{Combine Departure Audit and Annual Audit}

The time is limited and workload is heavy during the leadership transition. It may reduce the audit quality if departure audit is done at the same time. Thus, if we integrate the annual audit and departure audit, we can not only ease the pressure of departure audit and improve audit quality, but also enable leaders to master the use of resources and adjust the policy of resource use in time. At the same time, the annual audit of natural resources can better divide successive officials' environmental responsibilities and solve the problem of lagging behind 
supervision of natural resources.

\subsection{Determine the Key Point of Audit According to Local Conditions}

China has a vast territory and natural resources differ in various parts of China, so it's necessary to determine the key point of audit according to local conditions. The water resources are rich in the eastern part of China, while short in the western part; the southern part is mainly forest, while the north is mainly grassland. When conducting natural resource assets departure audit, each province should decide to focus on what kind of natural resources on its own actual conditions. For example, Yunnan should carry out the pilot work which focused on forest resources. Shandong and Inner Mongolia should focus on the audit methods of marine resources and mineral land resources respectively.

At the same time, we should use risk oriented audit method to pay close attention to those rare natural resources, but sample audit the natural resources which the public is not very concerned about. It can save manpower and material resources. Rational allocation of audit resources will improve the audit efficiency.

\subsection{Cultivating Compound Audit Talents}

Natural resource assets departure audit on leading cadres is a combination of environmental audit and financial audit. There are many types of natural resources, such as land, sea and so on. It leads to require auditors have related industries background or understand relevant natural resources' administrative regulations and policies. Therefore, we should train auditors to improve audit quality. Carry out professional environmental knowledge training regularly to cultivate compound audit talents.

\section{References}

[1] (2014) Research Group on Sustainable Development Strategy. Chinese Academy of Sciences, 149-150.

[2] People's Republic of China Audit Office. http://www.audit.gov.cn/

[3] Chen, B. (2014) On the Objective and Content of the Natural Resource Assets Departure Audit. Friends of Accounting, 36, 11-13.

[4] Anhui Provincial Audit Office Research Group. Thought on Accountability Audit of Natural Resource. Audit Research, 6, 3-9.

[5] Huang, R.B. and Zhao, Q. (2015) Discussion of Preparation and Audit on Natural Resource Balance sheet. Auditing Research, 1, 37-43.

[6] Luo, S. (2014) Compiling Natural Resource Balance Sheet in Three Types. Chinese Accounting Newspaper, 8, 1-2. 